\title{
The Curious Case of Cú Chulainn: Nationalism, Culture, and Meaning Making in the Contested Symbols of Northern Ireland
}

*Forthcoming: Studies in Ethnicity and Nationalism*

Gregory J. Goalwin

Department of Sociology, Aurora University

Aurora, IL U.S.A.

\begin{abstract}
:
While scholars have long recognized the importance of symbols to nationalism, most analyses examine relatively unambiguous symbols. I seek to understand how such processes function when symbolic meaning is contested, analyzing how organizations on both sides of the conflict in Northern Ireland deployed representations of Cú Chulainn to support conflicting political programs. I argue that movements in Northern Ireland imbued symbols with meaning by emplotting them within ideological narratives. In return, these symbols provided evidence that strengthened and supported the ideological narratives of the movements that produced them, serving as potent reminders of the worldview such narratives advocate.
\end{abstract}

\section{Biographical Note:}

Gregory Goalwin is Assistant Professor in the Department of Sociology at Aurora University. His research examines religion, culture, and the formation of ethnic and national identity, with particular focus on Ireland and the early years of the Republic of Turkey. 


\title{
The Curious Case of Cú Chulainn: Nationalism, Culture, and Meaning Making in the Contested Symbols of Northern Ireland
}

\author{
When Pearse summoned Cuchulain to his side. \\ What stalked through the post Office? What intellect, \\ What calculation, number, measurement, replied? \\ W.B. Yeats 'The Statues'
}

Visual imagery has long been a potent medium for expressing political and cultural ideas. This is particularly true in the case of nationalism, where symbols and representations of the nation provide an important means of crafting and reaffirming national identity. Indeed, several scholars of nationalism have argued that, more than simply representing it, such symbols form a crucial constituent element of the nation, defining and shaping membership and identity (Armstrong 1982; Smith 1987). And yet, as several recent studies note, despite this centrality to some of the most important strands of scholarly thought on nationalism the ways that nationalist movements and political organizations produce and interpret national symbols remains surprisingly understudied (Geisler 2005; Marsland 2001; Elgenius 2011; Smith 2013). While scholars have long recognized the power of symbols, comparatively little attention has been paid to the analysis of national symbols and the ways in which they are imbued with significant political and cultural meanings, coming to serve as visual representations of national identity. Furthermore, those studies which do emphasize national symbols (McCartney 1994; Elgenius 2011; Smith 2013) rely on them being relatively unambiguous, clear expressions of political and social ideas. Many scholars have focused on the ways in which national communities are created symbolically and imaginatively (Anderson 1983; Cohen 2013), but the fundamental processes by which ethnic entrepreneurs transform vague and ambiguous representations of the nation into hardened symbols of divisive versions of nationalism remain opaque. Such work is particularly important given that, as Victor Turner (1964) and others have argued, symbols are inherently polysemic and multifocal, drawing their meanings from the social and cultural contest in which they are used. This study seeks to remedy this deficiency by examining how these processes of symbolism and community formation develop. Here I trace how organizations on both sides of the conflict in Northern Ireland, a region famous for its political imagery, deployed the same symbol, representations of the Irish hero Cú Chulainn, in political murals throughout the region. Though the two sides utilized the exact same image, they did so to further diametrically opposed political goals, seeking to develop and support ideological narratives that presented radically different versions of Irish history and society.

Symbols of the nation often seem relatively straightforward and unambiguous. Flags, crests, and other such symbolic expressions of identity seek to present a simplified picture of the nation, distilling it to one easily digestible image that can stand in for the far more complex reality of the nation. This simplicity is unsurprising, symbols are most useful for identity purposes if they are easily understandable and present complex concepts as simple realities. Yet this simplicity is often misleading, as Michael Billig reminds us (1995), even the most seemingly banal expressions of national identity are intimately connected with ideological narratives that 
seek to present national identity and national history in a way that supports political claims. But what happens when such symbols are more ambiguous? When national symbols are not simple, but hold contested meanings? When the same symbol is claimed by groups seeking to promote not only widely varied, but diametrically opposed ideological narratives? How do ethnic entrepreneurs mobilize contest symbolic resources to tell a particular story about a national community?

The images of Cú Chulainn that appeared on political murals in Northern Ireland provide a useful case for answering questions such as these. Traditions of mural painting and symbolic expression have a long and powerful history in the conflict in Northern Ireland (Loftus 1990, 1994; McCartney 1994; Bryan et al. 2010), but the two duelling traditions, loyalist and republican, rely on significantly different repertoires of symbolic imagery. Cú Chulainn is rare in that his likeness is one of very few symbols that appear in murals produced by organizations on both sides of the conflict. ${ }^{1}$ This position as a multivocal political symbol makes Cú Chulainn a unique resource for scholars seeking to understand the ways that political movements use symbols. Methodologically, juxtaposing the ways that opposing groups utilize the same symbol to accomplish conflicting goals brings the political nature and ideological purpose of these images into stark relief. Examining the ways that groups imbued the image of Cú Chulainn with two antithetical meanings gives powerful insight into the way political processes of identification occur. If, as Clifford Geertz has argued, man is 'suspended in webs of significance he himself has spun' (Geertz 1973: 5) this study seeks to understand how cultural and political entrepreneurs spun significance and made meaning in an effort to strengthen ideological narratives on both sides of the conflict. I argue that political movements in Northern Ireland imbued national symbols such as Cú Chulainn with meaning by emplotting them within ideological narratives. These narratives shaped and gave significance to visual symbols, producing national myths that sought to structure the ways in which members of society viewed the world. In return, once established, these symbols and myths provided evidence which reciprocally strengthened and supports the ideological narratives of the movements that produced them, serving as potent visual reminders of the ideological view of the world such narratives are designed to support.

\section{Symbols, Identity, and Boundary Formation}

The study of symbols and their relationship to identity has a long history. Scholars as early as Durkheim recognized the power of collective symbols. In his famous work on totemism, Durkheim argued that the transference of emotions from concrete relationships to abstract symbolic concepts helps maintain the collective identity of a group when members lose contact with each other (1995 [1912]: 232). In this sense, symbols reduce the complexity of communication by using concrete signs as shorthand for larger concepts and ideas of community and collectivity. Though his formulation has been influential, Durkheim's explanation of this phenomenon is problematic; he argued that this process of signification occurs through a sort of natural 'spontaneous attachment,' a mystical and unsatisfactory explanation for a complex and often deeply political process. Indeed, as Michael Geisler has argued, there is nothing inherent in national symbols for meaning or emotion to spontaneously attach to (2005: XXVII). Attachment to national symbols occurs instead through constant repetition in the media, in politics, and

\footnotetext{
${ }^{1}$ In addition to Cú Chulainn, scholars such as Bill Rolston (1998) have identified symbols such as the Red Hand of Ulster, the Ulster Flag, the shamrock, and the phrase 'Erin Go Bragh' as the only comparable shared images between the two sides.
} 
throughout everyday life as social actors continually reinforce the relationship between symbols and the ideas and concrete relationships they are intended to represent (Geisler 2005: XXVIII). In this, symbols play an almost ritualistic role, emphasizing and signifying larger social constructs (Turner 1964). Indeed, such functionalist accounts as the ones put forward by Durkheim pay little attention to the social movements and political organizations involved in the production and interpretation of the symbolic and commemorative objects that structure the formation of collective identity (Saito 2010). Though recent efforts have sought to ameliorate this deficiency by drawing attention to the ways that groups and organizations seek to mobilize, support, and use rituals of commemoration and different versions of collective memory to advance their own political causes and claim symbolic legitimacy (Turner 1964; Wagner-Pacifici and Schwartz 1991; Zolberg 1998; Vinitzky-Seroussi 2002; Zubrzycki 2009), little enough scholarly attention has been paid to the fact that 'all commemorative rituals are permeated by dynamics of political contention, albeit to different degrees (Saito 2010: 633). This is true of all commemorative forms but is even more pronounced when commemorative symbols have contested meanings, used to promote divergent political and ideological narratives by opposing groups.

Efforts to promote such contested political and ideological narratives have been particularly important amongst nationalist movements, who have often sought to create a sense of national identity, history, and tradition, often in the face of competing historical and political claims from colonial or other national states. Several scholars of nationalism have recognized the power of national symbols for defining and solidifying ethnic and national identity. For Anthony D. Smith shared repertoires of cultural symbols help promote ethnic cohesion and solidarity. Though there is more to nations than myths and memories, he argues, 'they represent a sine qua non: there can be no identity without memory (albeit selective), no collective purpose without myth' (1987: 2). In Smith's view, analysis of an ethnic group's myths and symbols, what he calls the 'myth-symbol complex', is essential if one seeks to grasp the 'special character of ethnic identities' (Smith 1987). Ethnicity, Smith goes on to argue, is largely 'mythic' and 'symbolic' in character, myths, symbols memories and values are carried in forms and structures that change only slowly, and so an ethnie's mythic and symbolic content helps drive and define ethnic and cultural identity itself. John Armstrong (1982) took a different approach to analysing symbols' role in ethnic and national identity. Whereas Smith emphasized the integrative functions of myths and symbols, Armstrong focused on their ability to impose boundaries, strictly differentiating an 'in-group' from a collective and alien 'Other.' In many ways this is the flip-side of Smith's emphasis on cohesion and solidarity. For Armstrong, symbols do help define collective identity, but do so through differentiation, rather than through emphasis on any particular reservoir of significant myths and symbols. In this view, symbols serve as powerful border guards, helping to define and police the boundaries of group identity. Indeed, here Armstrong draws heavily on the influential work of Anthropologist Fredrik Barth, who argued that it is the boundaries themselves, rather than the 'cultural stuff' they enclose that truly matters for the creation and maintenance of ethnic and national identity (1969). This boundary-oriented approach allows for changes and variations in both biological and cultural content of a specific ethnic group over time. No matter what changes occur, the group can remain coherent as long as the boundaries separating it from those outside the group remain firm.

These formulations, emphasizing the ways that national myths, symbols, commemorations, and memories help create and shape national identity through processes of 
inclusion and exclusion are useful and have contributed much to the study of nationalism. For all their importance, however, these approaches rely upon symbols being relatively unambiguous and easily identifiable signifiers of the political and national identities and ideals they are meant to convey. This is, indeed, sometimes true, but in other cases national symbols can prove far less definitive, and multiple organizations and movements with varying political goals can employ similar symbols for wildly different purposes. How then, in such cases, do contested symbols acquire their meaning? What methods do political groups use to ensure that the symbolic expressions of identity they employ convey the proper signification and fulfil their intended purposes?

\section{Narrativity, Ideology, and National Culture}

One way to approach the issue of national symbols is to view them as expressions of, and an effort to build, a distinct national culture. As such, symbolic representations of the nation serve an explicit ideological purpose. Yet such expressions of culture do not operate identically across all social contexts. In her theoretical approach to the ways that culture functions within society, Ann Swidler argues that there is a distinction between the ways culture functions in what she calls 'settled' and 'unsettled' lives. In settled lives, she explains, culture tends to function to reveal a society's values and interests. But in unsettled lives, specifically articulated cultural patterns such as ideologies play a much more powerful role in organizing social life. 'In such periods, ideologies -explicit, articulated, highly organized meaning systems (both political and religious)- establish new styles or strategies of action' (Swidler 1986: 278). These ideologies acquire such power because they help structure societies that are culturally and politically in flux following the breakdown of established cultural forms that accompanies unsettled periods. In unsettled societies, such as, for example, Northern Ireland during the Troubles, these ideologies offer explicit unified answers to the question of how society should be organized and people should act, 'rather than providing the underlying assumptions of an entire way of life, they make explicit demands in a contested cultural arena' (Swidler 1986: 279). Indeed, these demands are so explicit because they urge patterns of action that do not necessarily come naturally, expressing pointed ideological arguments in an effort to reshape culture and society alike to better serve their world view.

While such ideologies function in a variety of ways, one powerful technique for expressing ideological perspectives is through narrative. As Gary Alan Fine has argued, social movements can even be defined as 'bundles of narratives' that can be deployed by social movement actors in an effort to strengthen commitment to the movement's goals and identities. Such narratives are powerful because 'the dramatic images provided by these stories, incorporated into group culture, provide a legitimated basis of community and collective action,' allowing groups with narrative cultures to better mobilize their members for action (Fine 2003: 134). In her work on the linkage between narratives and identity construction, Margaret Somers identifies the ways this process takes place. Somers argues that 'narratives are constellations of relationships (connected parts) embedded in time and space, constituted by causal emplotment' (Somers 1994: 616). And indeed, it is this connectivity and causal emplotment that proves a crucial element in the way narratives are employed. Somers argues that narrativity provides the meaning of any single event only in relationship to other events: understanding is only possible by 'connecting (however unstably) parts to a constructed configuration or a social network or 
relationships (however incoherent or unrealizable) composed of symbolic, institutional, and material practices' (Somers 1994: 616)

It is in this fashion that narrativists are able to make meaning, stringing together diverse and chaotic historical events into easily understandable guiding narratives that explain the world. These narratives are not merely representational, but are often ontological, shaping actors' and movements' world views, actions, and even self-identities. Narrative provides a framework in which salient historical events have been selected and structured in advance by a narrator, who causally emplots such events and relates them to an audience. One key aspect of this process is that it contains an element of evaluation. Narrativists selectively appropriate the most powerful events, symbols and social experiences in order to construct and support their guiding narratives, and will often 'tailor reality to fit their stories'. (Somers 1994: 618). The key to narrative's power is the way that these carefully selected events are woven together to create a cohesive story. As Somers argues, selected events are causally emplotted within the master narrative, set within a larger network of events and symbols. It is this process which imbues isolated events with powerful meanings. Events and symbols are made understandable in the context of narrative by giving them historicity and relationality, explaining relevant episodes in relation to the grander narrative course of carefully selected historical events.

Here again, Swidler provides a model for how this might work. Swidler 'offers an image of culture as a 'tool kit' of symbols, stories, rituals, and world-views, which people may use in various configurations to solve different kinds of problems' (Swidler 1986: 273). In this formulation, culture then is causally significant not for the end values it imparts, but because it provides cultural components that are used to construct strategies of action. Swidler argues that, crucially, 'all real cultures contain diverse, often conflicting symbols, rituals, stories and guides to action' (Swidler 1986: 277). Culture thus does not serve as a monolithic unified system that pushes society towards a particular goal, but rather serves as a repertoire, a reservoir from which actors can draw important symbols to help them construct differing lines of action. Groups and social movements carefully select powerful events, symbols, and social markers from the reservoir of such things operating in any given society and repurpose them, using them to help structure and support specific ideological worldviews.

Elsewhere in her work Swidler elaborates on how these selected cultural symbols and events acquire their relevant meanings. Swidler explains that the context within which such symbols are placed works to create larger ideological meanings for previously isolated and disconnected events and images. This process occurs on two distinct levels (Swidler 1995). First is the context of immediate face to face meeting, where different ideas are brought into close contact. In such settings the dynamic of the immediate context is often enough to provide a coherent systematic influence that brings coherent and ambivalent ideas into direct dialogue. The second level on which context operates is the larger, more general situation of societal and political conflict and accommodation in which the social movements and political actors function. At this level ideas, symbols, and actions acquire meaning from the larger processes and narratives that structure society, events and ideas are constantly interpreted and reimagined to fit within the ideological and rhetorical narratives that help structure the way people view the world. It is a combination of these levels of context that gives events and symbols their meanings.

These theoretical perspectives can be powerful tools for understanding the ways in which Northern Ireland's muralists sought to use the image of Cú Chulainn. Muralists on both sides of 
the conflict selected the symbol of Cú Chulainn in an effort to convey the ideological narratives that shape their own wildly conflicting political and cultural world views. Both traditions commemorate Cú Chulainn in an effort to gain symbolic legitimacy, connecting their own modern political movement with an ancient and legendary historical past. In Saito's terms, they both seek to transform historical (even if mythological) knowledge into collective memory, making their own interpretation of the Cú Chulainn symbol crucial to their particular groups' social and cultural identities. Both groups did this by emplotting the myth of Cú Chulainn into a restructured historical narrative that portrays the history of Ireland in a way that better fits their own ideological perspective. In this regard images of Cú Chulainn gain their meaning both through the immediate context of their location and through the context of the larger historical narratives in which they are embedded. Thus imbued with powerful ideological meanings, such images then serve as crucial forms of evidence which reinforce and strengthen those very same contested ideological narratives from which they originally gained their political significance.

\section{Northern Ireland, Murals, and Cú Chulainn}

Northern Ireland has long been a contested region where significant social conflict has accompanied a political struggle over the region's political status. Since the 1921 partition of the island of Ireland, nationalist groups have sought to reunite Northern Ireland with the independent Republic of Ireland, while unionist groups have sought to maintain and strengthen the region's position within and ties to the United Kingdom. These repeated clashes culminated in the Troubles, an armed conflict that lasted from 1968 to 1998, though scattered and lower level political violence continues to this day. While the conflict is largely a political one, concerned with issues of civil rights and self-determination, culture has served as one of the most important sites in which the conflict has been expressed (Bryan and McIntosh 2005). Political sentiments have been articulated through literature (Grant 1999), music (Zimmermann 2002), language (Crowley 2005), and sport (Sugden and Bairner 1993), yet perhaps the most visible way in which culture played into, and has helped shape, the conflict in Northern Ireland is in the dramatic visual presence of political wall murals that dominate the cityscape in Belfast and Derry, Northern Ireland's two largest, and most contested, cities. Such murals presented ideological arguments, crafting and displaying images and messages of the two political movements involved in the conflict. These efforts paralleled the physical conflicts between the two sides, expressing rhetoric and ideology in what Jeffrey Sluka has called a 'war of words and symbols' (1996) that played a crucial role in the political battle between the two competing sides. The rhetorical arguments conveyed by these murals thus offer crucial insight into the inner political workings of nationalist and unionist groups alike, revealing the ways that both sides worked to shape both their own identities and the historical narratives they use to define and express them.

The two mural traditions, nationalist and unionist, varied significantly in their origins, history, and subject matter. The unionist tradition of mural painting dates back more than a century, and until the 1980s was confined almost exclusively to proceedings surrounding the Twelfth of July, a holiday celebrating the ascendancy of Protestant culture over Catholicism at the Battle of the Boyne in 1690. The nationalist mural tradition had far more recent origins, arising following Bobby Sands' call, during the 1981 prison hunger strikes that would result in his death, 'that 'a massive Paint and Poster campaign' and a painting spree 'that would cover the countryside' should be started in order to put pressure on the British government and increase awareness and support for the prisoners' (Jarman 1997: 234). Unionist mural imagery tended to fall into three major categories: 1) depictions of historical events, 2) symbolic expressions of 
identity such as flags, crests, and coats of arm, and 3) portrayals of armed and threatening paramilitary soldiers. Republican murals were more varied, and tended to fall into five main themes: 1) depictions of the hunger strikers and other martyrs to the republican cause 2) memorials to other, often innocent, victims who died in the conflict, 3) claims to continuity with other revolutionary and civil rights movements around the world, 4) symbolic expressions of identity such as flags, crests and coats of arms, and 5) representations of paramilitary soldiers and the armed struggle itself (Goalwin 2013: 199, 205). In both cases, political muralists had carefully chosen repertoires of cultural symbols and images on which they drew, and there was very little overlap between them. The rarity with which symbols were shared between the two sides makes it even more striking when muralists deliberately chose to utilize symbols, such as Cú Chulainn, that had contested meanings.

Cú Chulainn was an Irish mythological hero, and one of the most prominent figures of the Ulster Cycle, one of the four main cycles of Irish mythology (Kinsella 1970). Depicting events traditionally thought to have taken place around the time of the birth of Christ, the Ulster Cycle portrays an Ireland not united under a central authority but fought over by competing local and provincial kingdoms. Cú Chulainn himself was a young warrior of the Kingdom of Ulster, famous for his ríastrad, a terrifying and all-consuming battle rage that turned him into an unrecognizable monster. For the competing ideological traditions in Northern Ireland, the most important legends of Cú Chulainn centre around his defence of Ulster from the invading armies of Queen Madb of Connaught, Ulster's neighbour to the southwest. According to the story, known as the Táin Bó Cúailnge (The Cattle Raid of Ulster), Queen Madb invaded Ulster in an effort steal the famous stud bull Donn Cúailnge. The rest of Ulster's army was overcome by a spell, leaving seventeen-year-old Cú Chulainn to face Madb's armies alone. Cú Chulainn successfully defended Ulster from the invaders from the south, waging a guerrilla campaign against them, and then defeating countless challengers in single combat at fords, holding out for months until Ulster's other defenders eventually revived (Kinsella 1970). Though in the original legends Cú Chulainn survived this trial, gravely wounded, later traditions have often conflated it with the story of Cú Chulainn's eventual death. In this story Cú Chulainn, once again defending Ulster from Madb's armies, was mortally wounded, but rather than lying down and succumbing to his wounds Cú Chulainn lashed himself upright to a nearby pillar of stone, so that he could die on his feet. His reputation for ferocity was so strong that his enemies feared to approach him even then, finally believing he was dead only when a raven landed on his shoulder. This image, of a slain Cú Chulainn lashed to his post, defending his country even after his death, provides a powerful rhetorical symbol, one which groups on both sides of the conflict in Northern Ireland have sought to exploit for their own purposes.

The image of Cú Chulainn that most often appeared on the walls in Northern Ireland is a specific one, freighted with significance to the conflict between nationalist and unionist movements. Nationalist and unionist murals depicted not just Cú Chulainn, but the same image of him, drawn from a nationalist statue that is housed in the Dublin General Post Office (GPO). The statue's location is politically significant as the GPO is, in its own right, a potent symbol within the political and cultural milieu of Ireland. Dublin's post office was the primary site of the ill-fated Easter Rising of 1916, in which Irish Republicans led by Patrick Pearse and James Connolly launched an armed insurrection in an effort to seize independence and end British colonial rule of all Ireland. The rebellion failed, and the surviving leaders of the movement were executed, but the Easter Rising remains an important cultural touchstone for the Irish Republican movement that still seeks to wrest Northern Ireland away from its union with the United 
Kingdom and reunite it with the rest of the island. The Dublin GPO houses the statue of Cú Chulainn, dead and tied to his rock in defiance of his enemies, in commemoration of the Rising, and the symbolic imagery of the statue urges the modern republican movement to live up to Cú Chulainn's example as a martyr willing to give his life for Ireland's security.

Cú Chulainn's status as a mythological figure from a distant past with no intrinsic connection to either modern movement made him a figure ripe for appropriation for political purposes. In this sense both sides of the conflict were engaged in producing what Eric Hobsbawm has famously described as an 'invented tradition' (1983), tying modern political struggles to a perceived mythical or historical past that would bolster ideological claims. This concept has come in for some criticism, but it is important to note that this process does not necessarily imply cold-hearted manipulation by political elites. Indeed, all traditions are in many ways invented, and in this case, as in others (Falasca-Zamponi 1998), groups on both sides sought to use symbols, myths, and memories in a formative way, helping to define their own sense of who they were and what they were fighting for. In using the image of Cú Chulainn both sides, first republicans in the early Twentieth Century then loyalists in response, have sought to draw upon cultural forms and symbolic reservoirs to construct a sense of their own collective identity.

\section{Contested Images and Contrasting Narratives: Cú Chulainn on the Walls}

The symbol of Cú Chulainn is one that held a reservoir of symbolic meanings that groups on both sides of the conflict could use. In their struggle for ideological supremacy in Northern Ireland both sides appropriated the image of Ireland's early hero and reinterpreted it, setting the image and myth of Cú Chulainn within larger political narratives that sought to legitimize their version of the region's history. Both sides did this by contextualizing the contested symbol of Cú Chulainn, displaying his image in conjunction with far less ambiguous symbols of national identity. This juxtaposition of imagery functioned on both of the contextual registers Swidler describes. In Northern Ireland murals were a widely used political medium. While murals were occasionally employed by apolitical groups, the production of murals was dominated by artists with connections to ideological organizations who took various elements of the conflict as their subject. In this regard, the larger processes and narratives operating in Northern Irish society provided murals with their first level of meaning, ensuring that such images were understood in a political way and cast in the context of the conflict between nationalists and unionists. On a more immediate register, images of Cú Chulainn drew their meaning from the associated national symbols that surrounded his image on murals produced by both sides. Such images left no doubt about which narrative the depiction of Cú Chulainn was meant to relate to. These murals each sought to claim the ambiguous symbol of Cú Chulainn and decisively incorporate it within their own political tradition, gaining control over a powerful symbol that could help bolster their efforts to assert ideological supremacy in the region.

The legend of Cú Chulainn, defender of Ulster to the point of, and even beyond death, is an attractive one to the republican movement in Northern Ireland. Republicans have long been faced with seemingly insurmountable odds, opposing the combined political might of the British and Protestant Northern Irish governments and the military strength of the British Army and loyalist paramilitary organizations. Indeed, for this reason, Cú Chulainn has frequently been used as a symbol by the republican movement, in addition to the physical statue in the Dublin GPO, muralists in Northern Ireland copied it several times, with iterations appearing in Armagh in 1991 and West Belfast in 1988 and 1997 (Rolston 1998). Yet despite this, Cú Chulainn himself 
is not necessarily an inherently republican symbol. Republican political usage of Cú Chulainn seems to date only to the early 20th century, a product of the 19th century Gaelic revival (Rolston 1998: 9), and of course, despite his symbolic association with the movement, Cú Chulainn himself was not a republican, the historical events underpinning the legend of Cú Chulainn, if there ever were any, occurred long before the conflict between nationalists and unionists in Northern Ireland. Indeed, as Sighle Bhreathnach-Lynch has shown, not all republicans were even comfortable with the adoption of Cú Chulainn as a symbol of the Irish republican movement (1997).

Despite its lack of deep historical roots, much work had been done to establish the image of Cú Chulainn as a republican symbol by the time muralists began incorporating it into their designs. Cultural nationalist works like those of Standish James O'Grady, Patrick Pearse, and Oliver Sheppard (Turpin 1997; O'Leary 1983) had firmly ensconced Cú Chulainn within the symbolic corpus of the republican movement. Republican muralists worked to continue and heighten this connection, contextualizing the image of Cú Chulainn by surrounding him with other republican symbols. Most popular of these were portraits of the ten republicans who perished in the 1981 hunger strikes. This depiction symbolically linked Ireland's ancient martyr to the republican movement's modern ones, making an explicit claim to the historicity and legitimacy of the modern movement. Accompanied by slogans such as 'Unbound - Unbroken' and 'I am Ireland, Great is My Glory' as well as the shields of the four provinces of Ireland united as one - these murals expressed the willingness of the republican movement to, like Cú Chulainn, fight to the death and beyond to achieve freedom.

This image fits well for a troubled movement that has faced both significant setbacks in the face of the overwhelming strength of its opponents and significant questions of legitimacy as it struggled to be seen as more than just a violent terrorist movement. Associating the ancient image of Cú Chulainn with the modern political movement contextualized modern events within a grander historical narrative of continued Irish struggle. By claiming Cú Chulainn as a republican, modern republicans were able to argue that their insecure current organization was but one expression of a larger, and surely legitimate, effort for national independence. Likewise, the murals' emphasis on martyrdom urged republican volunteers to, in Swidler's terms, undertake 'patterns of action that do not come naturally.' Continued resistance to overwhelming odds even to the point of death is a challenging proposition. By contextualizing deaths in service to the movement and placing them within a shared narrative of heroic sacrifice dating back all the way to ancient times, republican muralists were exhorting modern volunteers to live up to their predecessors' examples, dedicating themselves to the cause no matter what the cost. At the same time, such images also conveyed pointed ideological messages meant for outsiders, asserting the continued strength and resilience of the movement, willing to keep fighting forever as republicans had been doing ever since Cú Chulainn himself.

Loyalist muralists and organizations value the image of Cú Chulainn for similar reasons, though they moved to adopt the symbol much later and with much less enthusiasm than their republican counterparts. In 1986 the Ulster Young Unionist Association argued that ceding the myth of Cú Chulainn to the republican cause was a mistake, and that 'neglect of an ancient heritage resulted in republicans being able to steal the legend from us' (Rolston 1998: 10). Organizations such as the paramilitary Ulster Defence Association (UDA) agreed and undertook efforts to promote the adoption of the Cú Chulainn myth as a loyalist symbol (McAuley and McCormack 1990). While other organizations such as the Ulster Volunteer Force (UVF) made occasional use of the symbol, it was the UDA's artists and propagandists who most promoted the 
idea that Cú Chulainn could serve as a loyalist, not merely republican symbol. In this, the UDA was spurred on by its commander, Andy Tyrie, who sought to reclaim Cú Chulainn and other elements of Irish traditional culture for the loyalist cause (McAuley and McCormack 1990). Much of this support was spurred by the profoundly problematic and largely discredited (see Nic Craith 2002: 93) academic work of Ian Adamson, who argued that rather than being a Celtic hero, Cú Chulainn represents a member of the Cruthin people, an ethnic group that was eventually driven from Ireland to what is now modern day Scotland, and served as the ancestors for the modern day Protestant Scottish settlers whose transplantation to Northern Ireland as colonizers by the British set the stage for the modern day conflict in Northern Ireland (Adamson 1974). From this viewpoint, far from being an 'Irish' hero, Cú Chulainn was a defender of Ulster from an Irish invasion from the south, much as loyalist paramilitary organizations imagine themselves to be. In this, loyalist symbology sought to reinterpret Cú Chulainn not as a native Irishman, but as the ancestor of a separate, more British version of Northern Irish identity, one that drew heavily on a connection with Britain. Despite the efforts of Adamson and Tyrie, the symbol of Cú Chulainn failed to catch on with the larger loyalist movement, and its use remained a relatively small-scale phenomenon, practiced mostly by the leaders of the UDA. Interestingly, however, it was its connection to republicanism that provided some of the ideological weight that Tyrie and his UDA compatriots were hoping to deploy. The loyalist mural depicting Cú Chulainn, which appeared in East Belfast in 1991 (Rolston 1998), utilizes the exact same image of him, copied, just as the republican murals were, from the GPO statue in Dublin. Loyalists thus sought to claim symbolic legitimacy for their cause by arguing that they too, like Ulster's greatest past hero, were willing to die defending their homeland from southern invasions. In this sense, the Loyalist use of Cú Chulainn as a symbolic image represents a direct appropriation of a symbol already in use by the Republican movement. More than just an image of defiant strength, then, loyalist use of Cú Chulainn represented a direct claim to the symbolic heritage of Ireland and a direct appropriation of Irish culture as their own, a claim that taunted republicans and argued the loyalist vision of history superseded and was the only legitimate vision of Irish history. The particular image of Cú Chulainn that was selected by loyalist muralists, taken as it was from an explicitly republican source, thus only emphasizes the struggle for control of symbolic resources in Northern Ireland.

Like republicans, loyalist murals sought to imbue the image of Cú Chulainn with meaning through context, a pursuit that was made even more important by the symbol's previous association with republicanism. With this in mind, loyalist muralists always accompanied Cú Chulainn with the crests of loyalist paramilitary organizations such as the UDA and the Ulster Freedom Fighters (UFF). Even more explicitly, loyalist murals informed viewers of exactly how they were supposed to view the image. Captions on several murals took care to make explicit the connection to and claim over Irish history and identified him as 'Cú Chulainn - Ancient Defender of Ulster from Irish Attacks over 2000 Yrs Ago' (Rolston 1995: 17). The image of Cú Chulainn was often accompanied by images of armed loyalist paramilitaries, with captions claiming that they were 'Ulster's Defenders, Past and Present.' Other tokens of loyalist identity such as depictions of the British Union Jack and the remembrance poppy were also common. Both expressed continued devotion to the United Kingdom, the last referencing the sacrifices of the largely Protestant Ulster Battalion that fought for the UK at the Battle of the Somme during World War I.

Loyalist use of the Cú Chulainn image in this way also emplotted him within the larger narratives that drove the loyalist movement. For all its political power, many scholars have 
remarked on the insecurity that marked unionist life, forever caught between British and Northern Irish identities and constantly fearful of being abandoned to reunification with the Republic of Ireland (McKay 2000; Bruce 1992; Nic Craith 2002). Continued reference to the United Kingdom and the sacrifices loyalists have made for the UK was meant to repeatedly reinforce the region's connection to and membership in the union. This constant insecurity is also revealed in loyalist refusal to 'abandon' the Cú Chulainn symbol to republican use and the constant effort to contest every ideological and historical claim put forth by the republican movement. In this, the use of Cú Chulainn reflects a response to a continuing tension in a loyalist identity that has long sought to balance its Irish context with the connection to the United Kingdom, which sustains it. Loyalist use of Cú Chulainn puts forth the argument that it was not the republicans but the unionists who were the victims of foreign aggression in the Northern Irish conflict. In this, the figure of Cú Chulainn represented a symbolic effort to claim a middleground sort of identity, one drawing upon traditional Irish mythology but reconceptualized to emphasize links to Britain. Grounding claims of loyalist identity in the ancient myth of Cú Chulainn, bolstered by Adamson's academic proselytizing, provided historical weight to ideological arguments about the legitimacy of the loyalist identity and cause. Recasting Cú Chulainn as an 'Ulsterman' defending the region from Irish invaders from the South also allowed loyalists to recast their own role in Northern Ireland. Rather than the invaders and aggressors that republican propaganda painted them as, such murals argued, loyalists were merely stolid defenders, protecting their land and people from foreign depravation.

\section{Conclusions}

As the preceding section has sought to show, the contested image of Cú Chulainn gained its meaning in Northern Ireland through its contextualization within the larger structuring narratives that drove groups on both sides of the conflict. By displaying the image in conjunction with unambiguous national symbols, muralists on both sides sought to claim symbolic ownership of an important mythological touchstone in Northern Irish society. In this regard, unambiguous symbols of national identity served as powerful symbolic border guards, enclosing and claiming ownership of the contested image of Cú Chulainn. These murals made explicit ideological claims, seeking to incorporate Cú Chulainn's mythos into their competing views of Northern Irish history. Cú Chulainn's image was not, in and of itself, a political image, it depicted a mythological figure far removed from the context of the modern-day conflict between unionists and nationalists. By displaying it in a highly politicized medium, contextualized by other highly political symbols, muralists helped forge a new ideological symbol that gave Cú Chulainn a powerful meaning within the contested sphere of Northern Irish cultural politics. Such efforts worked because they emplotted Cú Chulainn within some of the most important ideological narratives that operated within groups involved in the conflict. For republicans, associating Cú Chulainn with the more recent example of volunteers lost in the hunger strikes helped cast him as just the first in a long line of Irish republican martyrs. Likewise, loyalist associations of Cú Chulainn with modern paramilitary 'defenders' contextualized him within a narrative, brought about by the siege mentality of much of Ulster unionism, that sees loyalist paramilitaries as waging a defensive struggle against the aggressions of Irish nationalism. Used in this way, the image of Cú Chulainn took on an entirely different meaning, cast as the prototypical loyalist paramilitary, protecting Ulster just his modern-day colleagues were seeking to do. 
At the same time as they drew their meaning from powerful ontological narratives, images of Cú Chulainn provided support for the ideological claims those narratives made about Northern Irish Society. Casting Cú Chulainn as the first Irish martyr allowed republican muralists to forge and strengthen a narrative of collective self-sacrifice. Such ideological messages exhorted modern republicans to live up to the examples of their illustrious ancestors. Images such as Cú Chulainn helped legitimize the republican movement, historicizing and contextualizing modern ideological arguments in a way that added support and urged patterns of action: continued resistance to British and unionist control. Similarly, loyalist depictions of Cú Chulainn sought to reinforce the narrative of unionists as harried defenders, presenting an image of them as the 'true' victims of the conflict in Northern Ireland, a difficult task given unionist domination throughout much of Northern Irish history. Engaged in a battle with republicans for ideological supremacy, loyalists too sought to legitimize their political claims. By recasting unionists as the descendants of ancient inhabitants of Northern Ireland, rather than colonizers from Britain and Scotland, loyalists sought to argue that their paramilitary efforts were defensive and legitimate, rather than the violent oppression nationalists sought to portray it as.

The contrasting ways in which loyalist and republican muralists displayed the image of Cú Chulainn provide insight into one way that nationalist movements can utilize contested symbols for ideological purposes. The use of Cú Chulainn as a political symbol by both sides, deployed in support of diametrically opposed visions of Northern Irish history, would seem to make the image thoroughly ambiguous, lessening its ideological weight and usefulness for political purposes. Muralists on both sides of the conflict were able to imbue the image of Cú Chulainn with significant symbolic meaning, however, by displaying it relationally and contextually, surrounding the Cú Chulainn image with unambiguous national symbols that explicitly informed viewers of how they were supposed to view the image, and which ideological narrative it related to. Once contextualized in such a manner and imbued with symbolic meanings that made them relevant to the cause, images of Cú Chulainn provided support for the ideological narratives that created them. These images bolstered narratives that sought to structure ways of viewing the world and exhorted specific patterns of action, ways of supporting such ideological worldviews and the political movements that endorsed them. Symbolic imagery, even when highly contested, thus served as a crucial tactic for groups on both sides of the conflict in Northern Ireland. Though the images were the same, the contexts, meanings, and narratives surrounding the depictions of Cú Chulainn on the walls were dramatically different, allowing muralists and political actors on both sides to incorporate the myth of Cú Chulainn into their ideologically charged narratives of Northern Irish history. 


\section{References}

Adamson, I. 1974. Cruthin : The Ancient Kindred, Newtownards, Nosmada Books.

Anderson, Benedict. 1983. Imagined Communities: Reflections on the Origin and Spread of Nationalism. London: Verso.

Armstrong, J. A. 1982. Nations before Nationalism, Chapel Hill, University of North Carolina Press.

Barth, F. 1969. Introduction. In: Barth, F. (ed.) Ethnic Groups and Boundaries. The Social Organization of Culture Difference. . Boston: Little, Brown.

Barthes, R. 1972. Mythologies, New York, Hill and Wang.

Bhreathnach-Lynch, S. 1997. The Easter Rising 1916: Constructing a Canon in Art \& Artefacts. History Ireland, 5, 1: 37-42.

Billig, M. 1995. Banal Nationalism, London; Thousand Oaks, Calif., Sage.

Bruce, S. 1992. The Red Hand : Protestant Paramilitaries in Northern Ireland, Oxford; New York, Oxford University Press.

Bryan, Dominic, and Gillian McIntosh. 2005. "Sites of Creation and Contest in Northern Ireland." SAIS Review 25 (2): 127-37.

Bryan, Dominic, Clifford Stevenson, Gordon Gillespie, and John Bell. 2010. "Public Displays of Flags and Emblems in Northern Ireland Survey 2006-2009."

Cohen, Anthony P. 2013. Symbolic Construction of Community. Routledge.

Crowley, T. 2005. Wars of Words the Politics of Language in Ireland 1537-2004, Oxford, Oxford University Press.

Durkheim, É. 1995. [1912]. The Elementary Forms of Religious Life, New York, Free Press.

Elgenius, G. 2011. Symbols of Nations and Nationalism: Celebrating Nationhood, Houndmills, Basingstoke, Hampshire; New York, Palgrave Macmillan.

Falasca-Zamponi, S. 1998. Of Storytellers and Master Narratives. Social Science History, 22, 4.

Fine, G. A. 2003. Public Narration and Group Culture: Discerning Discourse in Social Movements. In: Klandermans, H. J. a. B. (ed.) Social Movements and Culture. London: UCL Press.

Geertz, C. 1973. The Interpretation of Cultures: Selected Essays, New York, Basic Books.

Geisler, M. E. 2005. National Symbols, Fractured Identities: Contesting the National Narrative, Middlebury, Vt.; Lebanon, NH, UPNE.

Goalwin, G. 2013. The Art of War: Instability, Insecurity, and Ideological Imagery in Northern Ireland's Political Murals, 1979-1998. International Journal of Politics, Culture, and Society, 26, 3: 189215. 
Grant, P. 1999. Breaking Enmities: Religion, Literature, and Culture in Northern Ireland, 1967-97, Basingstoke, Hampshire; New York, Macmillan ; St. Martin's Press.

Hobsbawm, E. J. \& Ranger, T. O. 1983. The Invention of Tradition, Cambridge and New York, Cambridge University Press.

Jarman, N. 1997. Material Conflicts: Parades and Visual Displays in Northern Ireland. Berg.

Kinsella, T. L. B. L. 1970. The Táin, London; New York, Oxford U.P.

Loftus, Belinda. 1990. Mirrors: William III \& Mother Ireland. Picture Press. 1994. Mirrors: Orange \& Green. Picture Press.

Marsland, D. 2001. National Symbols. In: Leoussi, A. S. (ed.) Encyclopaedia of Nationalism. New Brunswick, N.J.: Transaction Publishers.

McAuley, James W, and Joe McCormack. 1990. "The Hound of Ulster and the Re-Writing of Irish History." Études Irlandaises 15 (2): 149-64.

McCartney, C. B. L. 1994. Clashing Symbols? : A Report on the Use of Flags, Anthems and Other National Symbols in Northern Ireland, Belfast, Institute of Irish Studies, Queen's University of Belfast.

McKay, S. 2000. Northern Protestants--an Unsettled People, Belfast, Blackstaff Press.

Nic Craith, M. 2002. Plural Identities--Singular Narratives: The Case of Northern Ireland, New York, Berghahn Books.

O'Leary, P. 1983. "What Stalked through the Post Office?": Pearse's Cú Chulainn. Proceedings of the Harvard Celtic Colloquium, 3, 21-38.

Rolston, B. 1995. Drawing Support 2: Murals of War and Peace, Belfast, Beyond the Pale.

Rolston, B. 1998. From King Billy to Cu Chulainn: Loyalist and Republican Murals, Past, Present, and Future. Eire-Ireland, 33, 1-2: 6-28.

Saito, H. 2010. From Collective Memory to Commemoration. In: Hall, J. R., Grindstaff, L. \& Lo, M.-C. (eds.) Handbook of Cultural Sociology. London; New York: Routledge.

Sluka, J. A. 1996. The Writing's on the Wall - Peace Process Images, Symbols and Murals in Northern Ireland. Critique of Anthropology, 16, 4: 381-94.

Smith, A. D. 1987. The Ethnic Origins of Nations, Oxford, UK; New York, NY, USA, B. Blackwell.

Smith, A. D. 2013. The Nation Made Real: Art and National Identity in Western Europe, 1600-1850, Oxford, Oxford University Press.

Somers, M. R. 1994. The Narrative Constitution of Identity: A Relational and Network Approach. Theory \& Society, 23, 5. 
Sugden, J. P. \& Bairner, A. 1993. Sport, Sectarianism and Society in a Divided Ireland, Leicester, Leicester University Press.

Swidler, A. 1986. Culture in Action: Symbols and Strategies. American Sociological Review, 51, 2.

Swidler, A. 1995. Cultural Power and Social Movements. In: Hank Johnston, B. K. (ed.) Social Movements and Culture. Minneapolis, Minn.: University of Minnesota Press.

Turpin, J. 1997. Nationalist and Unionist Ideology in the Sculpture of Oliver Sheppard and John Hughes. The Irish Review, 20: 62-75.

Vinitzky-Seroussi, V. 2002. Commemorating a Difficult Past: Yitzhak Rabin's Memorials. American Sociological Review, 67, 1: 30-51.

Wagner-Pacifici \& Schwartz, B. 1991. The Vietnam Veterans Memorial: Commemorating a Difficult Past. The American journal of sociology., 97, 2: 376-420.

Zimmermann, G. D. 2002. Songs of Irish Rebellion: Political Street Ballads and Rebel Songs, 1780-1900, Dublin, Ireland; Portland, Or., Four Court Press.

Zolberg, V. L. 1998. Contested Remembrance: The Hiroshima Exhibit Controversy. Theory and Society, 27, 4: 565-90. 